Dept. of Biochemistry,

Animal Health Research Institute, Dokki.

\title{
OXIDATIVE STRESS AND SOME HAEMATOBIOCHEMICAL CHANGES IN BLOOD OF CATTLE DURING THEILERIOSIS
}

(With 7 Tables and 6 Figures)

By

\section{AMAL M. HOSNY, SAHAR A. ALY and OMIMA I. AHMED*}

* Dept. of Parasitology, Animal Health Research Institute, Dokki.

(Received at 20/2/2010)

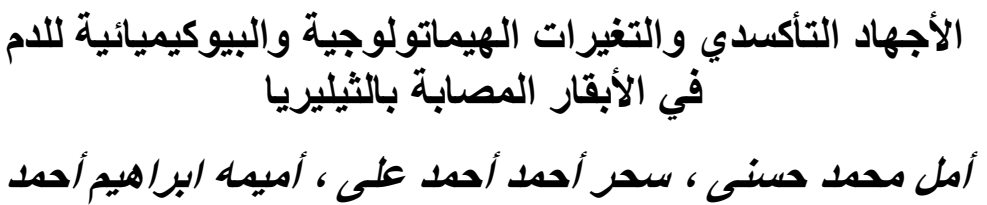

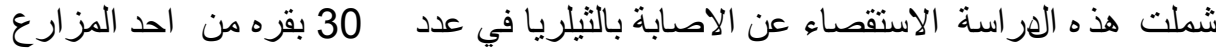

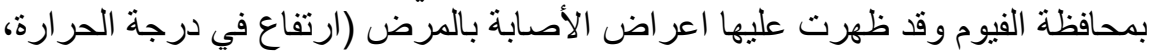

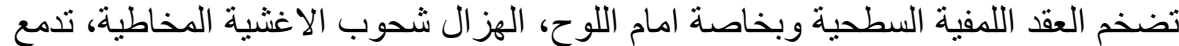

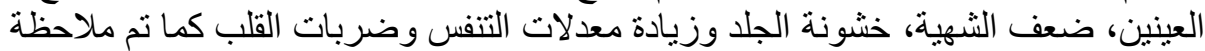

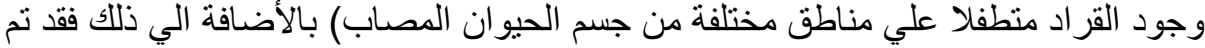

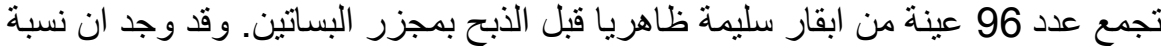

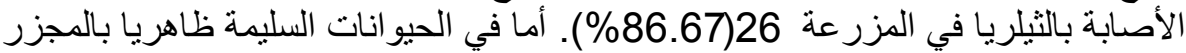

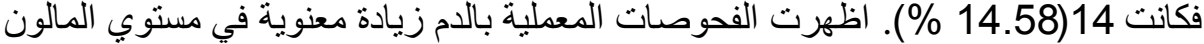

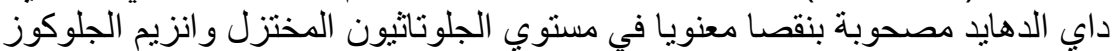

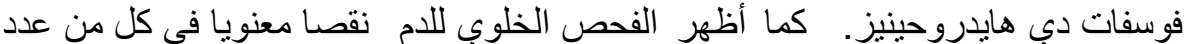

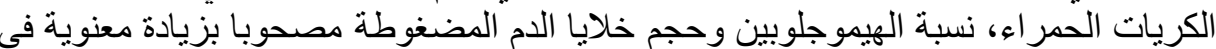

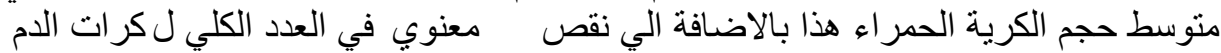

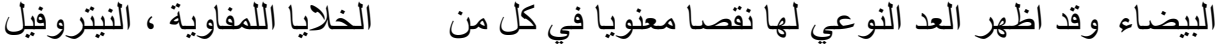

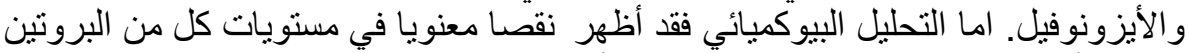

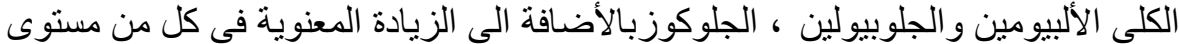

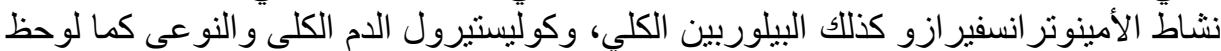

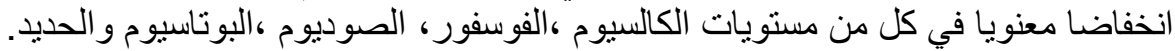

\section{SUMMARY}

Investigation of the oxidative stress and some heamato- biochemical changes associated with Theileriosis in cows: The prevalence of Theileria infection was investigated in 30 cows from a private farm in 
Fayoum Governorate with suspected symptoms of theileriosis such as rise in temperature, enlargement of superficial lymph nodes, inappetance, tachycardia, weakness. In addition, a total of 96 blood samples were collected from apparently healthy cattle before slaughtering at EL-Bassatine abattoirs. Further more, 20 positive samples for theileriosis were subjected to investigation of the oxidative stress and some heamato- biochemical changes. In addition, samples from 10 microscopically negative healthy cows were subjected to the same examinations as a control Parasitological examination revealed that the incidence of Theileria infection in the farm was 26(86.67\%) and in the apparently healthy cows at EL-Bassatine abattoir was 14(14.58\%) with a total incidence of $40(31.58 \%)$. Blood analysis of positive samples for theileriosis revealed a significant increase in erythrocytic malondialdehyde level (MDA) accompanied by a significant decrease of reduced glutathione (R.GSH) as well as glucose-6- phosphate dehydrogenase (G6PD). Heamatological examination showed a significant decrease in total red blood corpuscles (T.RBCs) count, Hemoglobin ( $\mathrm{Hb} \%), \mathrm{PCV} \%$, (packed cell volume) accompanied by a significant increase in $\mathrm{MCV}$ (mean corpuscular volume) in addition to significant decrease in T.L.C, (total leucocytic count) neutrophils, eosinophils and lymphocytes numbers. Biochemical analysis of positive cases revealed significant decrease of glucose, total proteins (T.P), albumin, globulin levels as well as albumin/globulin ratio (A/G), in addition to a significant increased levels of aminotranseferases, $\mathrm{T}$. Bilirubin, and cholesterol, whereas a significant decrease in iron, sodium, potassium, calcium and inorganic phosphorus, were recorded compared to the control group.

Key words: Theileria, cows, oxidative stress, hematology, serum biochemistry.

\section{INTRODUCTION}

Tropical theileriosis, a tick borne haemoprotozoan disease caused by protozoan parasite of the genus Theileria, and transmitted by Hyalomma sp., is one of the most devastating blood parasite-affecting cattle. (Sayin et al., 2003). The prevalence, morbidity, and mortality of tropical theileriosis are considerably high. It is estimated that 250 million cattle endemic are as from the Mediterranean basin to China, causing serious economic losses through bovine mortality and lost of productivity (Aktas et al., 2004). In their mammalian hosts, the parasites have a complex life cycle. Infection is initiated by the transformation of macroschizont-infected cells in the lymph nodes draining the site of 
inoculation of sporozoites by ticks. The infective form of the parasite is the sporozoite transforming into schizonts in WBCs of the mononuclear lineage. The schizont undergoes further differentiation to merozoites, which are released upon lysis of the infected cells. Once released from host cells, the merozoites enter erythrocytes. This is followed by the development of piroplasms in erythrocytes and the parasite becomes infective for the vector (Nalbantogiu, 2003). In the arthropod vector, the different stages of theileria species develop in gut epithelial cells and salivary glands till reaching the sporozoite which is the infective stage to the mammals (Shkap et al., 2003).

Weakness, weight loss, anorexia, high body temperature, petechia on the conjunctival mucosa, swollen lymph nodes, anemia, and cough are the most common clinical symptoms in theileriosis. On later stages of theileriosis, infected animals cannot stand up. Their body temperatures are under normal values and icterus, dehydration, and blood in feces are occasional clinical symptoms (Bakheit, et al., 2004). The main symptom of this disease is anemia; however, the pathogenesis of this anemia is not clear. It has been reported that abnormal osmotic fragility and morphological erythrocyte disorder were observed according to parasitemia, that the erythrocyte survival rate declines with the parasitemia, and that these phenomena occur in both parasitized and un parasitized erthrocytes (Yagi et al., 1998).

The occurrence of parasites produces lesions in the endothelial lining of blood vessels, tissue damage in organs such as liver, kidney, lung, and multiple petechial haemorrages (Forsyth et al., 1999).

There are some evidences that the oxidative stress and lipid peroxidation incorporate theileriosis in the pathogenesis of anaemia. Lipid peroxidation is a general mechanism, which, by free radicals, induces tissue damages and is involved under several pathological conditions (Halliwell and Gutteridge, 1999; Knight, 1995). Free radicals have been reported to act as cytotoxic agents (Gutteridge, 1995). The erythrocyte, due its role as $\mathrm{O} 2$ and $\mathrm{CO} 2$ transporter, is under constant exposure of free radicals (Harvey, 1997). However, red cells have a potent antioxidant protection that modifies free radicals into substantially less reactive intermediates (Cimen, 2008). Oxidative stress arises when there is an imbalance between radical-generating and radical-scavenging activity. It may therefore cause an increase in the formation of oxidation products (Gutteridge, 1995). Oxidation of the erythrocytes induces membrane injury, methemoglobin (MetHb) formation and eventually destruction of the cell (Harvey, 1997). Lipids 
especially polyunsaturated fatty acids are sensitive to oxidation, leading to the term lipid peroxidation, of which, malondialdehyde (MDA) is the most abundant (Halliwell and Chirico, 1993; Esterbauer, 1996). The accumulation of MDA in tissues or biological fluids is indicative of the extent of free radical generation, oxidative stress and tissue damage (Gutteridge, 1995; Yagi, 1998)

The present study aimed to focus light on prevalence of Theileria infection in cows and detection of some stages of Theileria in hard ticks. The present investigation also, was undertaken to ascertain the changes in hematological and biochemical constituents of blood as a result of Theileria infection in cows.

\section{MATERIALS and METHODS}

A total number of thirty cows from a private farm in Fayoum Governorate of both sexes with suspected symptoms of theileriosis were bled and examined for Theileria infection. The animals were clinically examined for signs of health and disease with special care to body temperature, nasal discharge, enlargement of superficial lymph nodes, corneal opacity and wasting (Radostits et al., 2000). In addition a total of ninety-six blood samples were collected from apparently healthy cows before slaughtering at EL-Bassatine abattoir. Blood samples were collected as two groups: the first, on silicone coated vacutainer tubes with EDTA (ethylene- diamine tetra acetate) for parasitological, oxidative and haematological examination. The second group on sterile Silicone- coated vacutainer tubes centrifuged at $3000 \mathrm{rpm}$ for 5 minutes to collect the serum for biochemical analysis. Thin blood smears were made from each blood sample, fixed and stained with Giemsa stain for detection of blood parasite microscopically according to Coles (1986). Collection of ticks from the body of animals. Ticks were prepared for dissection according to Rosell- Davis and Coons (1989). Both the salivary glands and the gut of each tick were taken separately and spread on a slide then stained with Giemsa stain. Developmental stages of these protozoa in blood films and salivary or gut smears were measured then illustrated.

After parasitological examination, 20 samples proved to be highly positive for theilaria were subjected to haematological and biochemical analysis. In addition, samples from 10 microscopically negative healthy cows were subjected to the same examination as control. 
The blood collected on (EDTA) for both groups was used for the determination of the following parameters represented in Table (1).

\section{Table 1:}

\begin{tabular}{|l|l|}
\hline \multicolumn{1}{|c|}{ Parameter } & \multicolumn{1}{c|}{ Reference } \\
\hline Malondialdehyde $(\mathrm{nmmol} / \mathrm{g} \mathrm{Hb})$ & Placer et al. $(1966)$ \\
\hline Reduced glutathione $(\mathrm{mmol} / \mathrm{L})$ & Beutler et al. (1963) \\
\hline Glucose-6-phosphate dehydrogenase $(\mathrm{u} / \mathrm{g} \mathrm{Hb})$ & Beutler. (1984) \\
\hline T.RBCs, WBCs count and Hb\% & Schalm (1986). \\
\hline PCV\%, MCV and MCHC\% & Jain (1986) \\
\hline
\end{tabular}

Blood film from each blood sample was stained with Leishman stain and observed microscopically to study WBCs differential count. The collected serum samples were used for the determination of the following parameters represented in Table (2).

\section{Table 2:}

\begin{tabular}{|l|l|}
\hline \multicolumn{1}{|c|}{ Parameter } & \multicolumn{1}{|c|}{ Reference } \\
\hline Serum Total protein $(\mathrm{g} / \mathrm{dl})$ & Hoffamann and Richterrich (1970) \\
\hline Serum Albumin $(\mathrm{g} / \mathrm{dl})$ & Dumas et al (1971) \\
\hline Serum Aminotranseferases (activity level) & Reitman and Frankel (1957) \\
\hline Serum Total Billirubin $(\mathrm{mg} / \mathrm{dl})$ & Ducci and Watson (1945) \\
\hline Serum Total Cholesterol (mg/dl) & Richmond (1973) \\
\hline Serum high density lipoproteins(mg/dl) & Warnick, et al (1983) \\
\hline Serum low density lipoproteins $(\mathrm{mg} / \mathrm{dl})$ & Steinberg (1981) \\
\hline Serum triglycerides $(\mathrm{mg} / \mathrm{dl})$ & Trinder (1969) \\
\hline Serum Glucose $(\mathrm{mg} / \mathrm{dl})$ & Kaplan (1984) \\
\hline Serum Calcium $(\mathrm{mg} / \mathrm{dl})$ & Glindler and King (1972) \\
\hline Serum inorganic Phosphorus $(\mathrm{mg} / \mathrm{dl})$ & Pasquinelli (1979) \\
\hline Serum Sodium $(\mathrm{mEq} / \mathrm{L})$ & Oser (1979) \\
\hline Serum Potassium $(\mathrm{mEq} / \mathrm{L})$ & Oser (1979) \\
\hline Serum Iron $(\mu \mathrm{g} / \mathrm{dl})$ & Smith et al (1981) \\
\hline
\end{tabular}

The mean values obtained from hemograms and biochemical assays of positive samples were compared with data of negative samples using the T- test (Petrie and Watson, 1999) Differences were considered to be statistically significant with values of $\mathrm{P}<0.05$ 


\section{RESULTS}

Table 3: The Prevalence of tropical theileriosis among cattle.

\begin{tabular}{|l|c|c|c|}
\hline & No. of animals & No. of infected & Percentage \\
\hline $\begin{array}{l}\text { Fayoum } \\
\text { farm }\end{array}$ & 30 & 26 & $86.67 \%$ \\
\hline Abattoir & 96 & 14 & $14.58 \%$ \\
\hline Total & 126 & 40 & $31.58 \%$ \\
\hline
\end{tabular}

Table 4: Effect of tropical theileriosis on oxidative stress indicators in cows

\begin{tabular}{|l|c|c|}
\hline \multicolumn{1}{|c|}{ Parameter } & Infected Group & Control Group \\
\hline MDA (nmmol/g Hb) & $90.00 \pm 3.09$ & $34.5 \pm 2.41$ \\
\hline R.GSH (mmol/L) & $2.90 \pm 0.096$ & $6.05 \pm 0.19$ \\
\hline G6PD (u/g Hb) & $15.83 \pm 0.60^{*}$ & $22.83 \pm 0.80$ \\
\hline
\end{tabular}

The mean difference is significant at the $\mathrm{P}<0.05$.

Table 5: Effect of tropical theileriosis on blood hematology in cows

\begin{tabular}{|c|c|c|c|c|c|c|c|c|c|c|c|}
\hline Parameter & T.RBCs & $\mathrm{Hb}$ & PCV & MCV & MCHC & TLC & lympho & Neutro & Eosino & Mono & Baso \\
\hline Groups & $\begin{array}{c}\times \\
\left(10^{6 / \mu 1)}\right.\end{array}$ & $\%$ & $\%$ & (fl) & $\%$ & $\begin{array}{c}\times \\
\left(10^{3} / \mu 1\right)\end{array}$ & $\begin{array}{c}\times \\
\left(10^{3} / \mu 1\right)\end{array}$ & $\begin{array}{c}\times \\
\left(10^{3} / \mu 1\right)\end{array}$ & $\begin{array}{c}\times \\
\left(10^{3} / \mu 1\right)\end{array}$ & $\begin{array}{c}\times \\
\left(10^{3} / \mu 1\right)\end{array}$ & $\begin{array}{c}\times \\
\left(10^{3} / \mu 1\right)\end{array}$ \\
\hline $\begin{array}{l}\text { Infected } \\
\text { Group }\end{array}$ & $\begin{array}{c}4.24 \pm \\
0.14^{*}\end{array}$ & $\begin{array}{l}8.52 \pm \\
0.16^{*}\end{array}$ & $\begin{array}{c}25.71 \pm \\
0.39 *\end{array}$ & $\begin{array}{l}61.70 \pm \\
1.53^{*}\end{array}$ & \begin{tabular}{|c}
$32.64 \pm$ \\
0.98
\end{tabular} & $\begin{array}{l}5.08 \pm \\
0.17 *\end{array}$ & $\begin{array}{c}2.47 \pm \\
0.06^{*}\end{array}$ & $\begin{array}{l}2.18 \pm \\
0.077 *\end{array}$ & $\begin{array}{l}0.16 \pm \\
0.005 *\end{array}$ & $\begin{array}{l}0.116 \pm \\
0.003\end{array}$ & $\begin{array}{l}0.027 \pm \\
0.002\end{array}$ \\
\hline $\begin{array}{l}\text { Control } \\
\text { Group }\end{array}$ & $\begin{array}{l}7.46 \pm \\
0.095\end{array}$ & $\begin{array}{c}11.43 \pm \\
0.23\end{array}$ & $\begin{array}{c}31.78 \pm \\
0.78\end{array}$ & $\begin{array}{c}42.64 \pm \\
.63\end{array}$ & $\begin{array}{c}34.64 \pm \\
0.53\end{array}$ & $\begin{array}{c}8.82 \pm \\
0.18\end{array}$ & $\begin{array}{c}4.59 \pm \\
0.09\end{array}$ & $\begin{array}{l}3.71 \pm \\
0.074\end{array}$ & $\begin{array}{l}0.28 \pm \\
0.004\end{array}$ & $\begin{array}{r}0.209 \pm \\
0.018\end{array}$ & $\begin{array}{l}0.045 \pm \\
0.002\end{array}$ \\
\hline
\end{tabular}

The mean difference is significant at the $\mathrm{P}<0.05$. 
Table 6: Effect of tropical theileriosis on some blood serum biochemical parameters in cows

\begin{tabular}{|l|c|c|}
\hline \multicolumn{1}{|c|}{ Parameter } & Infected Group & Control Group \\
\hline Total Protein (g/dl) & $5.77 \pm 0.10^{*}$ & $7.48 \pm 0.077$ \\
\hline Albumin(g/dl) & $2.30 \pm 0.066^{*}$ & $3.31 \pm 0.06$ \\
\hline Globulins(g/dl) & $3.32 \pm 0.05^{*}$ & $4.14 \pm 0.12$ \\
\hline A/G ratio & $0.63 \pm 0.04^{*}$ & $0.80 \pm 0.06$ \\
\hline ALT activity level (IU/L) & $29.66 \pm 1.77^{*}$ & $13.62 \pm 0.50$ \\
\hline AST activity level (IU/L) & $54.00 \pm 1.75^{*}$ & $24 . \pm 1.18$ \\
\hline Total Billirubin(mg/dl) & $1.45 \pm 0.019^{*}$ & $0.77 \pm 0.02$ \\
\hline Total Cholesterol(mg/dl) & $190.2 \pm 2.78^{*}$ & $146.0 \pm 4.20$ \\
\hline H D L(mg/dl) & $77.3 \pm 2.19^{*}$ & $53.3 \pm 1.79$ \\
\hline L DL(mg/dl) & $96.0 \pm 2.74^{*}$ & $71.5 \pm 2.56$ \\
\hline Triglycerides(mg/dl) & $18.0 \pm 0.85$ & $14.0 \pm 1.18$ \\
\hline Glucose(mg/dl) & $42.33 \pm 2.25^{*}$ & $62.51 \pm 1.85$ \\
\hline
\end{tabular}

The mean difference is significant at the $\mathrm{P}<0.05$.

Table 7: Effect of tropical theileriosis on some mineral concentration in cows

\begin{tabular}{|l|c|c|}
\hline \multicolumn{1}{|c|}{ Parameter } & Infected Group & Control Group \\
\hline Calcium(mg/dl) & $7.55 \pm 0.11^{*}$ & $9.95 \pm 0 . .07$ \\
\hline Inorganic Phosphorus $(\mathrm{mg} / \mathrm{dl})$. & $4.37 \pm 0.08^{*}$ & $5.51 \pm 0.14$ \\
\hline Sodium $(\mathrm{mEq} / \mathrm{L})$ & $128.5 \pm 1.50^{*}$ & $148.3 \pm 1.71$ \\
\hline Potassium $(\mathrm{mEq} / \mathrm{L})$ & $4.37 \pm 0.10^{*}$ & $5.65 \pm 0.11$ \\
\hline Iron $(\mu \mathrm{g} / \mathrm{dl})$ & $66.50 \pm 2.03^{*}$ & $104.66 \pm 2.6$ \\
\hline
\end{tabular}

The mean difference is significant at the $\mathrm{P}<0.05$. 

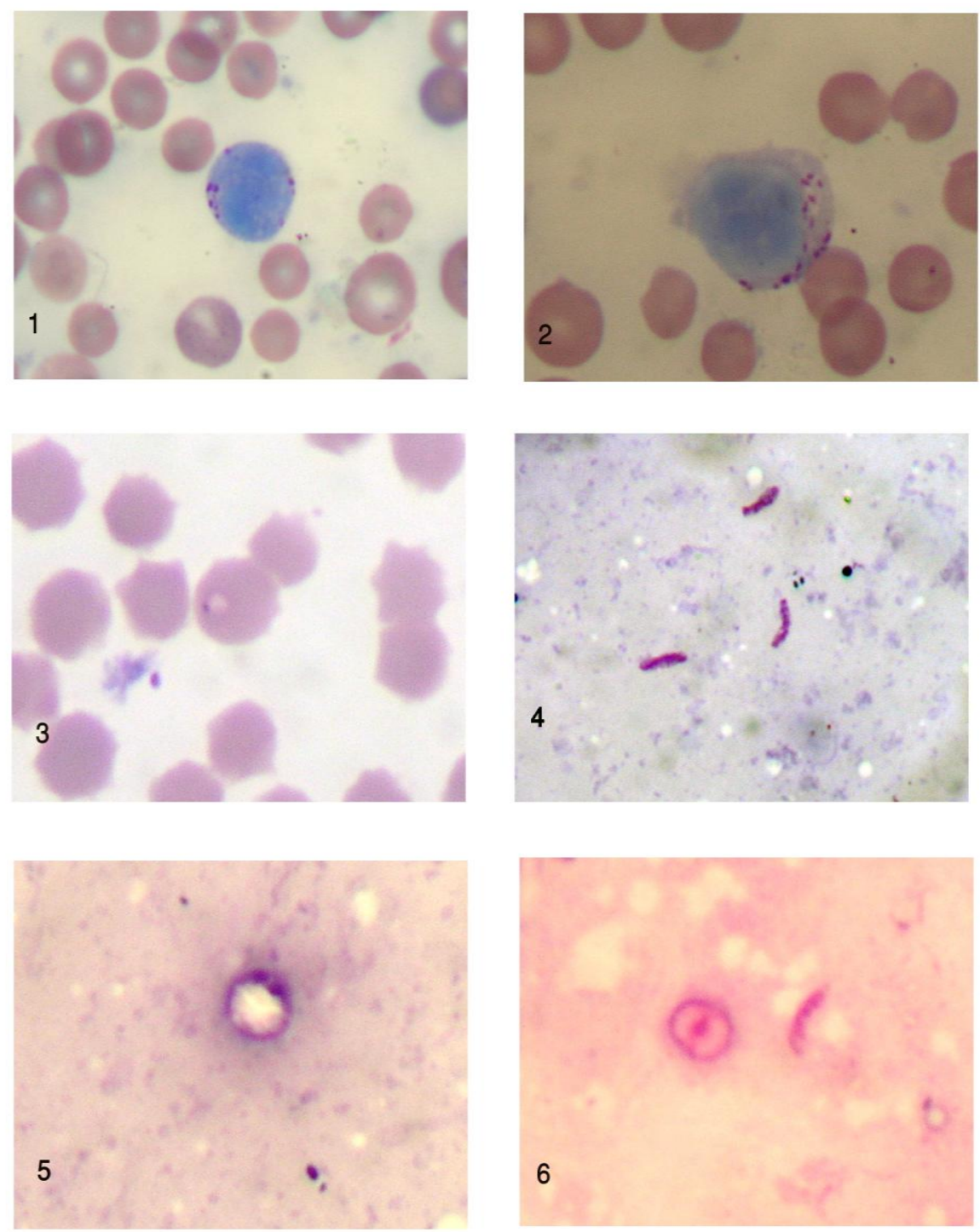

Fig. 1: Macroshizont in lymphocyte of blood smear of infected cattle Fig. 2: Microshizont in lymphocyte of blood smear of infected cattle Fig. 3: Ring form of theileria species within infected erthrocytes Fig. 4: Elongated form in gut smears from tick.

Fig. 5: Ring form in gut smears from tick.

Fig. 6: Ookinete in salivary gland smears from tick. 


\section{DISCUSSION}

\section{1- Parasitological examination}

The clinical signs on Theileria infection in cattle were rise in body temperature, enlargement of superficial lymph nodes, inappetance, tachycardia and weakness.

In the present study, the parasite was found to occur in different morphological forms within the thin blood smears. The schizonts were detected in the lymphocytes with two forms; macroschizonts and microschizonts. Macroschizonts measured 8.5× $3.5 \mu \mathrm{m}$ (Fig.1). Microschizonts measured $9.75 \times 3.75 \mu \mathrm{m}$ (Fig.2.). Ring form was found in infected erthrocytes with transparent central part and nucleus located at the margin was found in most cases and measured $1.3 \mu \mathrm{m}$ (Fig.3).

Regarding tick examination, various developmental stages of different shapes and forms were observed in the gut and salivary smears. Elongated structure was found in the gut smear, measured $3 \mu \mathrm{m}$ long with 2 nuclei were seen (Fig.4). and ring form was detected also in the gut smear measured $1.85 \mu \mathrm{m}$ (Fig.5) Concerning salivary gland smears examination revealed numerous sporonts (ookinete). Each one was round and measured 3-4 $\mu \mathrm{m}$ in diameter with centrally located nucleus a hallow was seen around the nucleus (Fig.6).

Mediterranean cost fever or tropical theileriosis is a tick born disease of cattle caused by Theileria infection, extending from Morocco to China and consider one of the major health problems of live stock (Devendra, 1995). Clinical examination of animals infected with Theileria revealed rise in body temperature, enlargement of superficial lymph nodes, loss of weight, anorexia. These findings were previously recorded by Abd EL-Raouf et al. (2000); Salah and Mahran (2003); Omer et al. (2003b) and El-Masry et al. (2006).

Examination of blood films (Table 3) revealed that 40 (31.58\%) out of 126 animals were infected with theileriosis. This result was similar to that of Loria et al. (1999); Abd EL-Raouf et al. (2000); Inoue et al. (2001) and El-Masry et al. (2006). They recorded that the incidence of theileriosis among cattle were $29.4 \%, 33.66 \% 27.5 \%$ and $29.33 \%$ respectively. However higher prevalence rates were reported by EL-Metenawy (2000); Inoue et al. (2001) and Song and Sang (2003) who detected that theileriosis among cattle were $76.5 \%, 50.4 \%$ and $67.8 \%$ respectively. These differences may be attributed to the difference in localities and species of examined animals. Also blood films revealed the presence of different forms of the intra erythrocytic 
trophoites, schizonts (Koch's blue bodies) in lymphocytes. This finding is completely typical to those previously described by Radostits et al. (2000); Salah and Mahran, (2003) and El-Masry et al. (2006).

The identification of the collected ticks revealed that they were Hyalomma anatolicum anatolicum. This result coincide with Bakhiet and Latif (2002); Shkap et al. (2003) and Aktas et al. (2004) who recorded that Theileria annulata, the causative agent of Tropical theileriosis in cattle, is transmitted by ticks of genus Hyalomma.

Tick examination revealed different developmental stages of Theileria, which were present in gut and salivary glands. Present result coincides with Schein (1975), who studied the life cycle of T. annulata in mid gut of Hyalomma anatolicum excavation, and found elongated structure measuring $3 \mu \mathrm{m}$ long with 2-4 nuclei, describing it as mature microgamont, whereas Magda et al. (1998) found elongated structure with 3 nuclei. Also a ring form measuring $1.85 \mu \mathrm{m}$ was observed. The latter stage may be the stage seen just after replication of ticks due to the similarity of its measurement with that of the ring form detected in the erythrocytes, which was $1.3 \mu \mathrm{m}$, this result was agreed with Magda et al. (1998).

Examination of the salivary glands revealed a round shape measuring 3-4 $\mu \mathrm{m}$ in diameter with centrally located nucleus and a hallow around it. This result is similar to those of Schein (1975) and ElRefai et al. (1998) who stated that the ookinete penetrated the alveoles of the salivary glands and commenced rounding up into sporonts.

\section{2- The Oxidative stress of Theileriosis:}

Since erythrocytes membrane is rich in polyunsaturated fatty acids, it is considered as the primary target for reactions involving free radicals, and is very susceptible to lipid peroxidation (Devasena et al., 2001).

Malondialdehyde (MDA), a product of polyunsaturated fatty acid oxygenation, is a reliable and a commonly used biomarker for assessing lipid peroxidation (Sheu et al., 2003). In present study, there was a significant increases $(\mathrm{p}<0.05)$ in the levels of MDA in Theileria infected cows, compared with healthy ones, In contrast, there was a significant reduction $(\mathrm{p}<0.05)$ in the level of R.GSH Table (4). These results come in accordance with Asri-Rezaei and Dalir-Naghadeh (2006) and Yoldas and Ertekin (2009). El- Deeb and Younis (2009) recorded that, increased MDA concentration with decreased levels of R.GSH, in affected cattle. It seems that such decreased level may be an indicator of high oxidative stress in theileriosis. The oxidative stress appears when 
the production of free radicals and reactive metabolites of oxygen exceeds their safe disposal by antioxidant mechanisms, causing lipid peroxidation and gave MDA as the finished product. Shiono et al. (2003) and Asri-Rezaei and Dalir-Naghadeh (2006) showed that the levels of MDA began to increase remarkably in proportion to the decrease of packed cell volume and the increase of parasitemia in $T$. sergenti infected cattle during the onset of anaemia. They added that, during the serious stage of anaemia, this oxidative index reached its maximum value, concluding that the oxidative damage to the RBCs might play an important role in the pathogenesis of anaemia in bovine theileriosis.

Morever, our results revealed a significant decrease $(p<0.05)$ in G-6-PDactivities in Theileria infected cattle, compared with healthy ones. This result come in accordance with El- Deeb and Younis (2009). The significant decrease in the activity of G6PD in affected cattle suffering of severe anaemia is an indicator of a metabolic disturbance of erythrocytes. This enzyme has a key role in the pentose phosphate pathway, which has critical significance in the survival of erythrocytes (Beutler, 1984). G6PD enzyme is the principal source of NADPH, which helps in maintaining glutathione at reduced state, thus protecting erythrocytes from oxidative stress. So G6PD serves as an antioxidant enzyme and the low activity of G6PD has been associated with increased haemolysis in cattle affected by theileriosis (Singari et al., 1991) and increased oxidative stress in endothelial cells (Leopold et al., 2003). Thus the, low G6PD activity can be followed by reduced activities of GSH, because of the dependence of the activity of this enzymes on $\mathrm{NADPH}+\mathrm{H}$ levels in the cell.

\section{3- Haematological examination}

In the present investigation, total red blood cells count, haematocrit value, and haemoglobin concentration were significantly lower $(\mathrm{p}<0.05)$ in infected cows compared to control group (Table 5): In addition, MCV, was significantly increased, where as MCHC was non significantly decreased indicating macrocytic hypochromic anaemia in the infected group compared to the control group. These observation were compatible with those reported by Beniwal et al. (2000); Omer et al. (2002); Ramazan and Ugur (2006); El-Masry et al. (2006); Abdellah et al. (2006); Hasanpour et al. (2008) and El-Deeb and Younis (2009). The cause of anemia during blood parasite infection may be multifactorial. The extent decrease in total RBC is correlated with the intensity of infection which indicated the destruction of erythrocytes and 
reduction in the $\mathrm{Hb}$ content as evidenced by anemia (Chengalva and Hafeez, 1995). The removal of the piroplasm- infected erythrocytes by macrophages in the organs of the reticuloendothelial system has been suggested as a cause of anemia. Beniwal et al. (2000) and Singh et al. (2001), recorded reticulocytosis to compensate increased RBCs destruction in theileriosis Also, this decrease could be due to increased levels of activated complement products (Stockham et al., 2000; Omer et al., 2002). In addition, pro-inflammatory cytokines, particularly TNF$\alpha$, have been implicated in mediating anemia associated with tropical theileriosis (Forsyth et al., 1999; Graham et al., 2001). Moreover, oxidized erythrocytes are easily destroyed by erythropagocytosis, and oxygen radicals may also be involved in the pathogenesis of the resultant anemia (Clark, et al., 1986; Mbassa, et al., 1994; Yagi, et al., 2002)

Some researchers have demonstrated an increased leucocytic number just after Theileria infection followed by a significant decrease within several days in calves, (Sandhu et al., 1998) and in camels (AlSaad, et al., 2006). Present data showed a significant decrease $(\mathrm{p}<0.05)$ in TLC, neutrophils, eosinophils and lymphocytes number accompanied by insignificant difference in absolute basophile and monocyte number in infected cows compared to the control ones (Table 5). Similar findings were reported by Omer et al. (2002); Ramazan and Ugur (2006); in cattle and with Osman and AL-Gaabary (2007); Hasanpour et al. (2008) and EL-Deeb and Younis (2009), in buffaloes, and with Hala and Eman, (2006), in sheep. This decrease was related to the destruction of lymphocytes in lymphoid organs and infiltration of these cells into various organs (Sandhu et al., 1998; Omer et al., 2002). Forsyth et al. (1999) suggested that Theileria infection induced leucopoenia in cattle, mainly mediated by TNF- $\alpha$. Graham et al. (2001) added that, cytokines (TNF- $\alpha$, IL-1, and IL-6) produced by infected mononuclear cells are responsible for the diverse clinical symptoms of tropical theileriosis, such as depression, pyrexia, anorexia, cachexia, and disseminated hemorrhages.

\section{4- Biochemical examination}

Serum proteins, albumin, globulins levels and A/G ratio, were decreased significantly $(\mathrm{P}<0.05)$ in the infected cows in comparison with the control group (Table 6). This results coincided with Farah et al. (1999); Omer et al. (2003a); Ramazan and Ugur, (2007) and Yurtseven and Uysal (2009) who attributed this decrease in total serum proteins to hypoalbuinaemia and hypoglobulinaemia arising from decreased protein production as a result of tissue damage in the liver which occurs during 
Theileria infection in cattle. Stockham et al. (2000), suggested that such decrease could be explained by the lesser food intake due to anorexia, in addition to the extravascular accumulation of pertinacious fluids, resulting from diseased lymph nodes and thus explained the edema and body cavity effusions.

In this investigation animals with theileriosis revealed a significantly higher level $(\mathrm{P}<0.05)$ of AST and ALT activity levels than the control group. (Table 5). These findings support the results of Sandhu et al. (1998); Singh et al. (2001); Omer et al. (2003a); Dabak et al. (2004); Ramazan and Ugur (2007), in cattle and with Hasanpour et al. (2008), in buffaloes, and with Hala and Eman, (2006), in sheep. The occurrence of parasites in any tissue causes the parasitic tissue damage (Radostitis et al., 2000). Theileria infection causes hepatic tissue damage that include coagulative necrosis, distortion of hepatic cord and heavy infiltration of lymphocytes in the peripheral areas, which indicate severe damage in the hepatobiliary system due to hypoxia resulting from anaemia and jaundice (Sandhu, 1998). Furthermore Ramazan and Ugur, (2007), recorded that, the significant rise in serum AST and creatine kinase activities in theileriosis were due to muscle trauma caused by prolonged recumbency.

In the same time a significant increase in bilirubin concentration in infected animals compared to control ones was observed (Table 6). This observation is in agreement with Sandhu et al. (1998); Farah et al. (1999); Omer et al. (2003a) and Ramazan and Ugur (2007), who related this rise in bilirubin concentration to the destruction of parasitized erythrocytes by erythropagocytosis in the spleen, lymph nodes and other organs of the reticuloendothelial system. In addition to the hepatic dysfunction and haemolytic anemia accompanying theileriosis.

Table (6) represents a significant increase $(\mathrm{P}<0.05)$ in the total cholesterol, HDL and LDL levels while triglyceride level showed no significant change, compared with the control ones. This result is in agreement with those of Yadav and Sharma, (1986) and Dabak et al. (2004) in cattle and with Hala and Eman (2006) who attributed these result to the liver damage.

In this study, theileriosis caused a significant decrease $(\mathrm{P}<0.05)$ in the concentration of serum glucose (Table 6). This result is in agreement with those of Dabak et al. (2004); El-Masry et al. (2006) and Ramazan and Ugur (2007) in cattle, and with EL-Deeb and Younis (2009) in buffaloes, who suggested that hypoglycemia could be due to the utilization of glucose by the parasite, in addition to the damaged 
liver. Also, Attia (2001) attributed hypoglycemia in blood parasite diseases to anorexia and depraved metabolic process of diseased animals.

In present study, cows with theileriosis showed a significant decrease $(\mathrm{P}<0.05)$ in calcium, inorganic phosphorus, sodium, potassium and iron levels, in comparison with healthy animals, (Table 7). These results are coincided with Farah et al. (1999); Omer et al. (2003a); Dabak et al. (2004); Ramazan and Ugur (2007), in cattle and with Hasanpour et al. (2008), in buffaloes, and with Hala and Eman (2006) in sheep. In theileriosis, hypocalcaemia and hyponatremia were probably due to the hypoproteinemia, decreased dietary intake, intestinal malfunction, and kidney damage (Ramazan and Ugur, 2007). Whereas, the decreased serum phosphorus concentration in cattle with theileriosis may resulted from the diarrhea and renal tubular defect (Sandhu et al., 1998; Omer et al., 2003a). Sodium and potassium are required to maintain electrolyte balance and osmotic pressure of the tissues. During theileriosis, animals suffer from severe dehydration, diarrhea and those parameters are thus found to be disturbed (Farah et al., 1999). The significant decrease in iron level may be attributed to the inability of the damaged liver to synthesize transferring, (Kumar and Malik, 1999; Omer et al., 2003a).

In conclusion, cattle theileriosis resulted in oxidative and heamato- biochemical changes, which may indicate of tissue damage and might form an indicative basis for subsequent studies, and it should be used as a useful tool for diagnosis, prognosis, and evaluation of the therapy applied.

Theileriosis in cows resulted in oxidative and heamatobiochemical changes, which may indicate tissues damage and might form an indicative basis for subsequent studies.

\section{REFERENCES}

Abdellah; M.R.; Abd EL-Fatah, A.M.; Abou El-Ella; Ghada A. and Raghib, M.F. (2006): Chain- breaking antioxidant, ascorbic acid and vitamin E, in response to cattle Theileriosis. Assiut Vet.Med.J.52 (108): 203-210.

AbdEL-Raof, Y.M.; Ramadan, M.Y. and EL-Sawalhy, A.A. (2000): Clinical and some biochemical changes associated with theileriosis in buffaloes.J.Vet. Med.Res., 2 (2): 75-84. 
Aktas, M.; Dumanli, N. and Angin, M. (2004): Cattle infestation by Hyalomma ticks and prevalence of theileria in Hyalomma species in the east of Turkey. Vet. Parasitol. J. 5, 119 (1)1-8.

Al-Saad, K.M.; Al-Obaidi, Q.T. and Al-Obaidi, W.A. (2006): Clinical hematological and biochemical study of theileriosis in Arabian one humped camels. Iraqi Journal of Vet. Science 20 (2): 211-218.

Asri-Rezaei, S. and Dalir-Naghadeh, B. (2006): Evaluation of antioxidant status and oxidative stress in cattle naturally infected with Theileria annulata. Veterinary Parasitology 142: 179-186.

Attia, H. (2001): Hematological and biochemical response to haemolytic anemia of clinical babesiosis in farm animals. Zag. Vet. J. 28 (2): 113-119.

Bakheit, M.A. and Latif, A.A. (2002): The innate resistance of Kenana cattle to tropical theileriosis (Theileria annulata infection) in The Sudan. Annals of the New York Academy of Science, 969: 159-163.

Bakheit, M.A.; Schnittger, J.; Salih, D.A.; Boguslawski, K.; Beyer, D.; Fadl, M. and Ahmed, J.S. (2004): Application of the recombinant Theileria annulata surface protein in an indirect ELLSA for the diagnosis of tropical theileriosis. Parasitol Res.; 92: 299-302.

Beniwal, R.K.; Sharma, R.D. and Nichani, A.K. (2000): Determination of duration of immunity of calves vaccinated with the Theileria annulata schizont cell culture vaccine. Vet Parasitol. 90:25-35.

Beutler, E. (1984): Glucose-6-Phosphate dehydrogenase (G6PD) and 6phosphogluconate dehydrogenase(6-PGD) red cell metabolism. A Manual of Biochemical Methods, Third Ed. Grune and Startton, Orlando, pp. 68-71

Beutler, E.; Duron, O. and Kelly, B.M. (1963): Improved method for the determination of blood glutathione. J. Lab. Clin. Med. 61: 882-888.

Chengalva, R.V. and Hafeez, M.D. (1995): Haematological values in cattle infected with Theileria annulata. Indian J. of Anim. Sci., 65 (11): 1202-1203.

Cimen, M.Y.B. (2008): Free radical metabolism in human erythrocytes. Clin. Chim. Acta 390, 1-11. 
Clark, I.A.; Hunt, N.H. and Cowde, W.B. (1986): Oxygen-derived free radicals in the pathogenesis of parasitic disease. Adv. Parasitol. 25: $1-44$.

Coles, E.H. (1986): Veterinary Clinical Pathology $4^{\text {th }}$ Ed. W.B. Saunders Company, Philadelphia, London and Toronto.

Dabak, M.; Dabak, D.O. and Aktas, M. (2004): Cerebral theileriosis in a Holstein calf. Vet. Record 154, 533-534

Devasena, T.; Lalith, S. and Padma, K. (2001): Lipid peroxidation, osmotic fragility and antioxidant status in children with acute post-streptococcal glomerulonephritis. Clin. Chim. Acta 308: 155-161.

Devendra, C. (1995): Animal production system in South-East Asia: potential and challenges for research In: Gardine, P., Devendra, C.(Eds) Global Agenda for Livestock research proc. of a consultation 18-20 January 1995, Nairobi, Kenya.

Ducci, H.J. and Watson, G.J. (1945): Determination of total serum bilirbuin. J. Lab. Clin. Med., 30: 293.

Dumas, B.T.; Wastson, W.A. and Biggs, H.G. (1971): Quantitative colormetric determination of albumin in serum or plasma. Clin. Chem. Acta, 31:87.

El-Deeb, W.M. and Younis, E.E. (2009): Clinical and biochemical studies on Theleria Annulata in Egyptian buffaloes with particular emphasis on oxidative stress and ketosis relationship. Cercetari Agronomice in Moldova Vol. XLII, 3 (139): 63-73.

EL-Masry Nabila, M.; EL-Dessouky, S.A. and Abo-Elkheir, S.A. (2006):

Parasitological and biochemical studies on cattle Theileriosis at Dakahlia Governorate with special reference to its control. Assiut Vet. Med. J. 52 (109): 165-178.

EL-Metanawy, T.M. (2000): Prevalence of blood parasites among cattle of central area of Saudi Arabia. Vet. Parasitol. Jan., 87(2-3): 231-236.

EL-Refaii Magda, A.H.; Wahba, A.A. and Gehan, J.S. (1998): Studies on Theileria infection among slaughtered camels in Egypt. Egypt. J. Med. Sci. 19 (1): 1-17.

Esterbauer, H. (1996): Estimation of peroxidative damage. A critical review. Pathol. biol. (Paris) 44: 25-28.

Farah Amani, W.; Soliman Ferial, A.; Gamal El-Din, H.Y. and Zein ELAbdin, A.M. (1999): Clinical changes in the blood of cattle vaccinated and infected with Theileria annulata. Vet Med. J., Giza 47 (2): 255-266. 
Forsyth, L.M.G.; Minns, F.C.; Kirvar, E.; Adamson, R.E.; Hall, F.R.; McOrist, S.; Brown, C.G.D. and Preston, P.M. (1999): Tissue damage in cattle infected with Theileria annulata accompanied by metastasis of cytokine-producing, schizont-infected mononuclear phagocytes. J Comp Pathol.; 120: 39-57.

Glindler, E.M. and King, J.D. (1972): Colormetric determination of calcium in biological fluids with methylene blue. Am. J. Clin. Path., 58: 376-382.

Graham, S.P.; Brown, D.J.; Vatansever, Z.; Waddington, D.; Taylor, L.H.; Nichani, A.K.; Campbell, J.D.M.; Adamson, R.E.; Glass, E.J. and Spooner, R.L. (2001): Proinflammatory cytokine expression by Theileria annulata infected cell lines correlates with the pathology they cause in vivo. Vaccine. 2001; 19: 2932-2944.

Gutteridge, J.M.C. (1995): Lipid peroxidation and antioxidants as biomarkers of tissue damage. Clin. Chem. 41, 1819-1828.

Hala, A.H.W and El-Kelesh Eman, A.M. (2006): Haematological and biochemical changes in blood of sheep suffering from Theileria infection.Proceedings of the $1^{\text {st }}$ joint Congress of the Egyptian Society for Animal and Poultry Management. 1 (1): 201-217.

Halliwell, B. and Chirico, S. (1993): Lipid peroxidation: its measurement, and significance. Am. J. Clin. Nutr. 57 (suppl.), 715S-725S.

Halliwell, B. and Gutteridge, J.M.C. (1999): Free Radicals in Biology and Medicine, Third Ed. Oxford University Press, New York, pp. 936.

Harvey, J.W. (1997): The Erythrocyte: Physiology, Metabolism and Biochemical Disorders. In: Kaneko, J.J., Harvey, J.W. (Eds.), M.L.Bruss Clinical Biochemistry of Domestic Animals. fifth ed. Academic press, London, pp. 157-203.

Hasanpour, A.; Moghaddam, G.A. and Ahmad, N. (2008): Biochemical, Hematological, and Electrocardiographic Changes in Buffaloes Naturally Infected with Theileria annulata_Korean J Parasitol. December; 46(4): 223-227.

Hoffamann, T.P. and Richterrich, R. (1970): Die El iminerony von Trubungen beider Bestimmung von plasma proteinam mitden Buiret Rasgenz. Z, Klin. Chem. U.K. in Biochem. 8: 595.

Inoue, M.; Van Nguyen, D.; Meas, S.; Ohashi, K.; Sen, S.; Sugimoto, C. and Onuma, M. (2001): Survey of theileria parasite infection in cattle in Combodia and Vietnam using piroplasm surface 
protein gene- specific polymerase chain reaction. J.Vet. Med. Sci., 63(10): 1155-1157.

Jain, N.C. (1986): In: Jain, N.C. (ED.) Schalms Vet Haematology $4^{\text {th }}$ Edition. Lea and Febiger, Philadelphia, p.p. 20-26.

Kaplan (1984): Clin. Chem. The C.V Mosby Co. St. Louis. Toronto, Princeton; 1032-1036.

Knight, J.A. (1995): Diseases related to oxygen-derived free radicals. Ann. Clin. Lab. 25, 111-121.

Kumar, R. and Malik, J.K. (1999): Influence of experimentally induced theileriosis on the pharmacokinetics of a long acting formulation of oxytetracyclin in calves. J.Vet. Pharma and Therapeutics, 22: 320-326.

Leopold, l.A.; Zhang, Y.Y.; Scribner, A.W.; Stanton, R.C. and Loscalzo, I. (2003): Glucose-6- phosphate dehydrogenase over expression decreases endothelial cell oxidant stress and increases bioavailable nitric oxide. Arterioscler Thromb. Vasc. Biol. 23: 411-417.

Loria, G.R.; Rilli, S.; Vitale, F.; Gveco, V. and Spargano, O. (1999): Clinical and Laboratory studies on theileriosis outbreaks in Sicily, Italy. Parasitologia, 41 Suppl, 1: 63-67.

Mbassa, G.K.; Balemba, O.; Maselle, R.M. and Mwaga, N.V. (1994): Severe anaemia due to haematopoietic precursor cell destruction in field cases of East Coast Fever in Tanzania. Vet Parasitol; 52: 243-256.

Nalbantogiu, ZS. (2003): Studies on the epidemiology of tropical theileriosis (Theileria annulata infection) in cattle in Central Anatolia Turkey. Trop Anim Health Produc. 35: 521-539.

Omer, OH.; El-Malik, K.H.; Mahmoud, OM.; Haroun, EM.; Hawas, A.; Sweeney, D. and Magzoub, M. (2002): Haematological profiles in pure bred cattle naturally infected with Theileria annulata in Saudi Arabia. Vet Parasitol. 107: 161-168.

Omer, O.H.; El-Malik, K.H.; Mahmoud, OM.; Haroun, EM.; Hawas, A. and Omer, H.M. (2003a): Biochemical profiles in Friesian cattle naturally infected with Theileria annulata in Saudi Arabia. Veterinary Research Communiccation.27 (1): 15-25.

Omer, O.H.; Haroun, E.M.; Mahmoud, O.M.; Abd El-Magied, E.M.; ELMalik, K.H. and Magzoub, M. (2003b): Parasitological and clinicopathological profiles in Friesian cattle naturally infected with Theileria annulata in Saudi Arabia. J. Vet. Med. B. Infect. Dis. Vet. Public Health, 50 (4): 200-203. 
Oser, B.L. (1979): in "Hawks Physiological Chemistry" $14^{\text {th }}$ ed. The Blakiston Division Mc Grow Hill Book Companies, New York, Tornto Sydney, and London.

Osman, S.A. and AL-Gaabary, M.H. (2007): Clinical, haematological and therapeutic studies on tropical theileriosis in water buffaloes(Bulbalus bulbalis) in Egypt. Veterinary Parasitology, 146: 337-340.

Pasquinelli, F. (1979): Diagnostica et technique di laboratorio. Rosini, Fireuz, 1070.

Petrie, A. and Watson, P. (1999): Statistics for Veterinary and Animal Science $1^{\text {st }}$ Ed., pp 90-99. The Blackwell Science Ltd, United Kingdom.

Placer, Z.A.; Cushman, L.L. and Johnson, B.C. (1966): Estimation of product of lipid peroxidation (malonyldialdehyde) in biochemical systems. Anal. Biochem. 16: 359-364.

Radostits, O.M.; Blood, D.C. and Gay, C.C. (2000): Veterinary Medicine, $8^{\text {th }}$ Ed. Baillier Tindall, London.

Ramazan, C. and Ugur, U. (2006): Haematological and coagulation profiles during severe tropical Theileriosis in cattle Turk. J. Vet. Animal Sci. 30: 577-582.

Ramazan, C. and Ugur, U. (2007): Changes in selected serum components in cattle naturally infected with Theileria annulata. Bull Vet. Inst. Pulawy 51: 15-18.

Reitman, S. and Frankel, S. (1957): A colorimetric method of pyruvic transaminases. Am. J. Clin. Path., 28: 57-63.

Richmond, W. (1973): Enzyme preparation for cholesterol investigation. Clin. Chem., 19: 1350-13656.

Rosell, D.R, and Coons, L.B. (1989): Relation ship between feeding, mating vitellogenin production and vitellogenesis in the Tick Dermacentor variabilis. Exper.and Appl. Acorol. 7.95: 105.

Salah, M.A. and Maharan, O.M. (2003): Parasitological and biochemical studies on acute tropical theileriosis in neonatal Friesian calves in the Egyptian oases. Assiut Vet. Med. 49 (99): 156-176.

Sandhu, G.S.; Grewal, A.S.; Sing, A.; Kondal, J.K.; Sing, J. and Brar, R.S. (1998): Haematological and biochemical studies on experimental Theileria annulata infection in crossbred calves. Vet Res. Commun. 22: 347-354.

Sayin, F.; Dincer, S.; Karaer, Z.; Cakmak, A.; Yukari, B.A.; Eren, H.; Vatansever, Z. and Nalbantoglu, S. (2003): Studies on the epidemiology of tropical theileriosis (Theileria annulata 
infection) in cattle in Central Anatolia, Turkey. Trop. Anim. Health Prod., 35: 521-539.

Schalm, O.W. (1986): Veterinary Haematology, $4^{\text {th }}$ Ed.Lea and Febiger, Pheladelphia, pp. 21-86.

Schein, E. (1975): Light microscopic studies on the development of Theileria annulata of Hyalomma anatolicum excavation. $\mathrm{Z}$. Parasitenk, 48: 123-136.

Sheu, J.Y.; Ku, H.P.; Tseng, W.C.; Chen, M.T.; Tsai, L.Y. and Huang, Y.L. (2003): Determination of thiobarbituric acid adduct of Malondialdehyde using online microdialysis coupled with high performance liquid chromatography Anal. Sci. 19: 621-624.

Shiono, H.; Yagi, Y.; Chikayama, Y.; Miyazaki, S. and Nakamura, I. (2003): The influence of oxidative bursts of phagocytes on red blood cell oxidation in anemic cattle infected with Theileria sergenti. Free Radic. Res. 37: 1181-1189.

Shkap, V.; Pipano, E.; Rasulov, I.; Azimov, D.; Savitsky, I.; Fish, L.; Krigel, Y. and Leibovitch, B. (2003): Protecolytic enzyme activity and attenuation of virulence in Theileria annulata Schizont infected cells. Vet. Parasitol. 29: 115 (3): 247-255.

Singari, N.A.; Bhardwaj, R.M.; Chugh, S.K. and Bhardwaj, S. (1991): Status of erythrocytic glucose-6- phosphate dehydrogenase in phosphorus deficiency haemoglobinuria of buffaloes. Vet. J. 68: 226-230.

Singh, A.; Singh, J.; Grewal, A.S. and Brar, R.S. (2001): Studies on some blood parameters of crossbred calves with experimental Theileria annulata infections. Vet Res. Commun.; 25: 289-300.

Smith, J.E.; Moore, K. and Schoneweiss, D. (1981): Colormetric technique for iron determination. Am. J. Vet. Res. 42: 1084-1085.

Song, K.H. and Sang, B.C. (2003): Prevalence of Thielaria sergnti infection in Korean native cattle by polymerase chain reaction. Korean J. Parasitol., 41 (3): 141-145.

Steinberg, D. (1981): Metabolism of lipoprotein reaction in cellular level in relation to atherogenesis in lipoprotein. Arteriosclerosis and Coronary Heart disease Journal. 2: 31-48.

Stockham, S.L.; Kjemtrup, A.M.; Conrad, P.A.; Schmidt, D.A.; Scott, M.A.; Robinson, T.W.; Tyler, J.W.; Johnson, G.C.; Carson, C.A. and Cuddihee, P. (2000): Theileriosis in a Missouri beef herd caused by Theileria buffeli: case report, herd 
investigation, ultra structure phylogenetic analysis and experimental transmission. Vet Pathol; 37: 11-2.

Trinder, F.T. (1969): Report of the national cholesterol. Educational program. Expert panel on detection evaluation and treatment of high blood- cholestrol in adults. Ann.clin. Biochem. 148:36-39.

Warnick, G.R.; Benderson, V. and Albers, N. (1983): Selected methods. Clin. Chem. 10: 91-99.

Yadav, C.L. and Sharma, N.N. (1986): Changes in chemical components during experimentally induced Theileria annulata infection in cattle. Vet. Parasito., 21: 91-98.

Yagi, Y.; Furuuchi, S.; Takahashi, H. and Koyama, H. (1998): Abnormality of osmotic fragility and morphological disorder of bovine erythrocyte infected with Theileria sergenti. Jpn. J. Vet. Sci. 51: 389-395.

Yagi, Y.; Thongnoon, P.; Shiono, H. and Chikayama, Y. (2002): Increase in oxidized proteins in Theileria sergenti-infected erythrocyte membrane. J. Vet. Med. Sci; 64: 623-625.

Yoldas, I. and Ertekin, A. (2009): Investigation of Haemoglobin Types and Glutathione Levels in Theileriosis Infected cattle. Veteriner Fakultesi Dergisi, 20 (1): 53-56.

Yurtseven, S. and Uysal, H. (2009): Decreased serum sialic acid, albumin-globulin ratio and total protein levels in cattle heavily infected with Theileria annulata. Ankara Univ. Vet. Fak. Derg, 56: 141-144. 
Assiut Vet. Med. J. Vol. 56 No. 125 April 2010 